preparation of the extensive series of potential antimalarials made in his laboratory. One of these, in which the side-chain of plasmoquine is replaced by $-\mathrm{NH}-\mathrm{CH}_{2}-\mathrm{CH}_{2}-\mathrm{CH}_{2}-\mathrm{NH}-\mathrm{CH}_{2}-\mathrm{CH}_{2}-\mathrm{CH}_{2}-\mathrm{NH}_{2}$, was found to have a chemotherapeutic index $1: 62$ against $1: 32$ for plasmoquine and is, therefore, a promising material for clinical trial. The necessary bird malaria tests on these substances are being made in Prof. Keilin's laboratory at Cambridge by Dr. Tate and Miss Vincent, and the former described the methods used. Inoculation of infected blood provides material for tests on asexual forms of the parasite, and birds infected by bites from mosquitoes are used for tests of activity against gametocytes and sporozoites, and details were given of the results of such investigations of a number of Prof. Robinson's substances.

The bird malaria test has also been applied to a number of other problems. Drs. Buttle and Trevan have shown that the interesting series of alkaloids isolated by Messrs. Goodson and Sharp from ten species of Alstonia have no action in bird malaria, and the same is true of the alkaloids of Picralima klaineana, though both these drugs have some repute in various tropical countries as remedies for malaria. The same workers made a comparative examination of specially purified specimens of the principal cinchona alkaloids and found that, as an anti-schizont drug in bird malaria, quinine was about twice as active as quinidine or cinchonidine, and possibly five times as active as cinchonine.

These results are of considerable interest in connexion with the use of mixtures of cinchona alkaloids as a cheap substitute for quinine, and justify the action of the Malaria Commission of the League of Nations in providing a standard for such mixtures, which prescribes a minimum content of fifteen per cent of quinine. Much work has also been done, particularly by Giemsa, in assessing the therapeutic value in bird malaria of 'modified cinchona alkaloids'. The results show that, so far, no product of this type is much better than quinine or dihydroquinine; but this work has provided a fund of information as to the influence on anti-malarial activity of modifications in the structure of drugs, which will probably be of great value in the biochemical and biophysical investigations, which are beginning to be made in the hope of ascertaining how and why such drugs exert their specific action. As an example of such work, mention may be made of the paper by Sir Rickard Christophers describing the methods he has used, and some of the results obtained in examining the view that chemotherapeutic effect is a result of some kind of combination between protein substance and the basic side-chains, which are a characteristic feature of effective antimalarial drugs.

It was particularly appropriate that the discussion should be introduced by Col. James, who has had special opportunities for clinical investigation of the new drugs, plasmoquine and atebrin. He provided a careful survey of their value as true causal prophylactics, as means of avoiding relapses and as preventives of spread of the disease, these being the principal characteristics of their action in which they surpass quinine, for they are to be regarded, not as substitutes for this alkaloid, but as additional weapons in anti-malarial campaigns.

Col. James finally expressed the hope that provision would be made in Great Britain for more intensive chemotherapeutical research. On the same point, Prof. Robinson emphasised the need for the closest co-operation between chemists and biologists in work of this kind, and Prof. Warrington Yorke pointed out that, although in a number of cases, such as sleeping sickness and amœbic dysentery, the first useful chemotherapeutical observation had been made by English workers, we had failed to follow up these observations by systematic pharmacological and chemical work, with the result that the countries of the Empire still had to depend largely on imported synthetic drugs.

T. A. H.

\title{
Obituary
}

\section{Mr. J. F. Herd}

$\mathrm{J}^{\mathrm{A}}$ AMES FLEMING HERD, senior scientific officer in the Radio Department of the National Physical Laboratory, died on July 22 at the early age of forty-seven years.

Born and educated in Dundee, Herd entered the Post Office, and became a highly skilled officer of the telegraph service. He served in the Royal Flying Corps and Royal Air Force, as an instructor in that part of the service which developed into the Wireless and Electrical School. Retaining the rank of flight lieutenant in the R.A.F. Reserve of Officers, he joined the Meteorological Office as a senior professional assistant, for service at Meteorological Office Radio Station, Aldershot, then engaged in a study of atmospherics in relation to thunderstorm detection. On the formation of the Radio Research Board, that station was taken over by the Department of Scientific and Industrial Research, to which its two scientific officers were seconded, later to become substantive 
members of the Department's staff. In the steady growth of the Department's organisation for radio research, he took a rapidly increasing load of responsibility, and the formation of the Radio Department, National Physical Laboratory, in 1933 brought him to the rank of senior scientific officer as officerin-charge of the Slough Division of the new entity, and as secretary of a number of committees of the Radio Research Board.

Herd's published scientific work falls far short of representing his notable contributions to the progress of fundamental radio research. He submerged his individual interests in the development of that teamworking which the Slough Station chose as its method of attack on the complex and varied problems in the pathology of radio communications entrusted to it for study. His contributions to the Proceedings of the Royal Society, the Journal of the Institution of Electrical Engineers and other papers, and his monograph (jointly with two departmental colleagues) on

The Cathode Ray Oscillograph in Radio Research" give some evidence of his rare gifts as an investigator. His gifts for scientific organisation did much towards the success of the London (1934) meeting of the Union Radio-Scientifique Internationale, in which he took an important part.

\section{Dr. F. C. Shrubsall}

Dr. Frank Charles Shrubsall died at his home in Hampstead on September 25, aged sixty-one years.

$\mathrm{He}$ was the only child of a master mariner. Never robust, his health during childhood gave anxiety to his family, and he was taken on several sea voyages. Thus, early in life he came in contact with differing types of men, and this aroused in him that intense interest in the study of mankind which was to shape his whole career.

Shrubsall was educated at Merchant Taylors' School and went up to Clare College, Cambridge, in 1892 with an entrance scholarship. He graduated in 1895 taking first class in the Natural Sciences tripos. He entered St. Bartholomew's Hospital and qualified in medicine in 1900 after a brilliant career as a student. Appointments at St. Bartholomew's and the Brompton Hospital for Chest Diseases gave him much experience in the practice of medicine, and intensified his interest in the study of human types. $\mathrm{He}$ proceeded to his M.A. degree at Cambridge in 1899 and took the M.D. in 1903 . His remarkable clinical gifts were speedily recognised; he was appointed in 1908 to a Hunterian professorship at the Royal College of Surgeons and elected to the fellowship of the Royal College of Physicians in 1912.

When the British Association met in Cambridge in 1904, Shrubsall read a paper in Section H (Anthropology) on the influence of selection by disease on the constitution of city populations. This paper at once established his position among British anthropologists. $\mathrm{He}$ became a secretary of Section $\mathrm{H}$ and for eighteen years continued to hold this onerous post. During this period, he contributed many articles to the Section of original and important character and did an immense amount of work on research committees.

The opportunities for continued research held out by the work of the school medical service attracted him, and in January 1909 he was induced to enter the service of the London County Council. Here he found immediate work to hand in the collating and analysis of an immense amount of raw material in the shape of physical measurements which had been collected. As the result of the growth of the work of the school medical service, Shrubsall found himself in 1912 attached to the headquarters staff in charge of the special school division. Thus began his association with problems of mental deficioney and juvenile delinquency, matters in which he was destined to become acknowledged the foremost expert in the country. Increasing pressure of public work compelled him to relinquish his secretaryship of Section $H$ in 1923, and he was elected president of the Section for the Toronto meeting in 1924. $\mathrm{He}$ took as the subject of his presidential address "Health and Physique Throughout the Ages".

At the time of his death, Shrubsall was a senior medical officer of the London County Council in charge of a section which included special and reformatory schools, mental deficiency, care of the blind, and medical examination of employees.

The value of Shrubsall's services to British anthro. pology and of his pioneer work in the sphere of public health, particularly that associated with the elucidation of the problems of mental deficiency and juvenile delinquency, cannot be too highly estimated. $\mathrm{He}$ was a man of great generosity and kindness of character, and was greatly beloved by all his coworkers in every sphere.

C. J. T.

WE regret to announce the recent death of Baron Léon Fredericq, emeritus professor of physiology at the University of Liege, at the age of eighty-four years. He was born in 1851 at Ghent, where he became doctor in natural science and medicine in 1871. After studying experimental methods in several foreign laboratories he became assistant in the Department of Physiology and Comparative Anatomy at the University of Ghent, where he carried out investigations on the presence of fibrinogen in the blood plasma. In 1879 he succeeded Theodor Schwann at Liege in the chair of physiology, which he held for more than forty years, during which he carried out important researches on the physiology of circulation, respiration and the nervous system. $\mathrm{He}$ was the author of a standard treatise on physiology and a handbook of technique and demonstrations in general and special physiology. At the beginning of the century he was the co-founder with Paul Héger of the Archives internationales de physiologie. He also founded a biological station for botanists and zoologists. Frédéricq was a corresponding member of the Institut de France, commander of the Legion of Honour and of the Crown of Italy and fellow of the Physiological Society of London, in addition to many other distinctions. 